\title{
Inbreeding Depression of Progenies of Castor Bean, From of the Variety FCA-PB, Results of Three Types of Pollinations
}

\author{
Jackson da Silva ${ }^{1}$, Andréia Rodrigues Ramos ${ }^{2}$, Deoclecio Jardim Amorim ${ }^{2}$, Maurício Dutra Zanotto ${ }^{2}$ \\ \& Maria Márcia Pereira Sartori ${ }^{2}$ \\ ${ }^{1}$ Department of Agriculture, Federal Rural University of Pernambuco, Recife, Pernambuco, Brazil \\ ${ }^{2}$ Department of Production and Breeding, School of Agriculture, São Paulo State University, Botucatu, São \\ Paulo, Brazil \\ Correspondence: Maria Márcia Pereira Sartori, Department of Production and Breeding, School of Agriculture, \\ São Paulo State University, Botucatu, São Paulo, Brazil. Tel: 55-143-880-7559. E-mail: \\ maria.mp.sartori@unesp.br
}

Received: May 22, 2019

Accepted: July 19, 2019 Online Published: September 30, 2019

doi:10.5539/jas.v11n16p68

URL: https://doi.org/10.5539/jas.v11n16p68

\begin{abstract}
Oil of castor bean despite its wide range of use, still present a relevant deficit in the Brazilian market. This deficit could be softened or extinguished with increased productivity, in which the genetic aspect has a great contribution. The most productive genotypes are the hybrid varieties, however for obtaining the hybrids pure lineages are required which have appropriate agronomic characteristics and that express the minimum of inbreeding depression. Thus, the objective of this research was to evaluate the inbreeding depression of castor bean progenies, from the cultivar FCA-PB, resulting from three types of pollination. The experiments were implanted in design in randomized blocks, in the $30 \times 3$ factorial scheme, being 30 progenies and 3 types of pollination (free, cross and self-pollination), in 2 environments (São Manuel and Araçatuba) and in 2 crops (2004/2005 and 2005/2006), with three replications. Inbreeding depression was estimated under the grain productivity variable. It was observed that cross-pollination presented grain productivity close to $2500 \mathrm{~kg} \mathrm{ha}^{-1}$, in which the lowest coefficient of inbreeding was determined, zero (0). Opposed It self-pollination, in which resulted in lower productivity, around $2000 \mathrm{~kg} \mathrm{ha}^{-1}$, and the highest inbreeding coefficient being of 0.77 . The reflection of the coefficient of inbreeding on productivity presents inversely proportional behavior, ie, the measure that increases the coefficient of inbreeding decreases the grain yield.
\end{abstract}

Keywords: breeding, inbreeding coefficient, frequency distribution, Ricinus communis L.

\section{Introduction}

Castor bean (Ricinus communis L.) is a crop with high socioeconomic value, thus being an important source of revenue for the country. The oil of this oleaginosa exhibits great relevance, due to the lack of adequate substitutes in many industrial applications (Chierice \& Luz Neto, 2007; Vieira \& Lima, 1999). Among its constituents, ricinoleic acid stands out in terms of the proportion and presenting molecules with properties and different structures among the other existing fatty acids in vegetable oils (Moshkin, 1986). These properties and differentiated structure confer peculiar characteristics to castor oil, allowing the use in more than 400 processes in the industrial and pharmaceutical área (Vieira \& Lima, 1999).

In the world scenario, Brazil presents itself as the fourth largest producer of castor bean, obtaining production of 24 thousand tons and productivity of $470 \mathrm{~kg} \mathrm{ha}^{-1}$. Having the State of Bahia the highest national production with 10.4 thousand tons, presenting productivity of $490 \mathrm{~kg} \mathrm{ha}^{-1}$ (FAO, 2016; CONAB, 2017). Despite the wide range of use of castor oil, Brazil imported, in the year of 2013, 5 thousand tons in oil (FAO, 2016).

In addition, obtaining productive genotypes adapted to the edaphoclimatic conditions of each producing region would be a strategy to increase productivity and decrease the import dependence of castor oil (Toppa et al., 2018). Being the hybrid varieties, which the provide the most uniform and productive plants, due to the fact of exploring the heterosis between pure lineages (Lopes et al., 2008).

However, to obtain these pure lines it is imperative that the populations have the minimum of inbreeding, because inbreeding can result in harmful effects, being defined as the mating system of individuals who have 
common ancestors, there being with that, higher probability that the offspring have copies of the same ancestral allele, which causes an increase in homozygosity and can increase the frequency of deleterious deleterious genes, which leads to a decrease in the vigor of hybrid (Gonçalves et al., 2011; Ramalho et al., 2012).

Thus, to obtain pure lines with the minimum of endogamy, which can result from the crossing between full siblings, half brothers, parents and children (backcrossing) and self-fertilization, it essential for breeding programs. Thus, the knowledge of the form of pollination that results in the lowest level of inbreeding is quite relevant (Borém, 2005, 2009; Bueno et al., 2006; Borém \& Miranda, 2013; Toppa, 2012).

Given the above, the objective of the present study was to evaluate endogamic depression of castor bean of progenies, from the cultivar FCA-PB, resulting from three types of pollination.

\section{Method and Methods}

\subsection{Obtaining Progenies}

At Winter Crop in 2003, both in the municipality of São Manuel and also in Araçatuba, were obtained progênies of open pollination, cross-pollination and self-pollination, in 30 plants of cultivar FCA-PB, making a total of 30 progenies for each type of fertilization.

The self-pollinated progenies were obtained by protecting the inflorescences in anthesis, with waterproof paper bags to contain the pollen and create the atmosphere of pollen grains inside the bag, favoring the fertilization of female flowers and avoid contamination with different pollens (Savy Filho, 2009).

In the case of progenies obtained by cross-pollination, the hybridizations were preceded by emasculation of the racemus of the female parent, what received the pollen, and then protected with paper bags of suitable size. For pollination, the pollen grains were obtained from a pollen mixture of 100 random plants of the original population of female flowers, then the pollen grains were scattered and later the bunches bagged (Savy Filho, 2009).

In the free-pollination progenies, no specific measures were taken, only the collection of seeds.

The seeds of the progeny were stored in a cold chamber to decrease their respiration, to keep it or lose as little as possible of the germination power and vigor of the seeds.

\subsection{Obtaining the Natural Crossing Rate}

The natural crossing rate was estimated in São Manuel and Araçatuba with the use of a morphological marker in the characteristic presence of aculeus, being that the lots of castor bean for this estimate had to be installed of form isolated by a minimum radius of $200 \mathrm{~m}$ between them. Each batch consisted of a compound with a recessive plant (ss), which conditions the absence of aculeous, and 100 dominant homozygous plants (SS), in which this allelic type expresses the aculeous presence. Thus, the natural crossover rate was given by the quotient between the number of heterozygous plants $(\mathrm{Ss})$ and the total number of plants by descente in recessive plants.

\subsection{Location and Characterization of Experimental Areas}

The experiments occurred in the 2004/2005 and 2005/2006 crop agricultural, during the months of October to May, simultaneously in São Manuel and Araçatuba. The climate of the city of São Manuel-SP, is of type Cfa, the average annual temperature is between 18 to $20{ }^{\circ} \mathrm{C}$, with average annual rainfall between 1000 and $1300 \mathrm{~mm}$ and altitude between 600 and 800 meters. As far as Aracatuba is concerned, according to the Köppen-Geiger classification, is classified as Aw, presenting an average annual temperature of $22.2{ }^{\circ} \mathrm{C}$, with annual average rainfall of $1206 \mathrm{~mm}$ and altitude around 401 meters (Alvares et al., 2014).

\subsection{Experimental Design and Treatments}

The experiments were randomized block design, in the $30 \times 3$ factorial scheme, being 30 progenies and three types of pollination (open pollination, cross pollination and self pollination), with three replicates. It is noteworthy that castor bean progenies were obtained from the FCA-PB population (developed by the Program of Breeding of UNESP/FCA).

\subsection{Installation and Conduction of Experiments}

Prior to the installation of the experiments, soil samples were drawn at a depth of 0.0 to $0.2 \mathrm{~m}$, being recommended the accomplishment of the fertilization of foundation with $400 \mathrm{~kg} \mathrm{ha}^{-1}$ of the manure formulated 04-14-08. 
Soil preparation consisted of two plows and two gradations, the grooves being then opened and distributed the fertilizer with a seeder-fertilizer tratorized, adjusted according to the spacing of $1.0 \mathrm{~m}$ between rows.

The planting of the experiments occurred in October 2004 and 2005, so that three seeds were deposited manually every $0.5 \mathrm{~m}$ of furrows, with depths between 4 and 8 centimeters. Ten days after the emergency, thinning was carried out, leaving only one plant.

The experimental plot occurred in 3 rows of $7 \mathrm{~m}$ in length, using the spacing of $1.0 \times 0.5 \mathrm{~m}$, in which the useful area was the central row, discarding the first two plants of each end.

In the initial phase of culture, it used the irrigation sprinkler system, with varying blade according to evapotranspiration of the castor bean, aiming to standardize the emergency plants.

The control of weeds occurred in three weeding operations, manually, during the whole cycle of castor bean, have seen the long cycle of it.

\subsection{Rated Characters}

The crops were harvested in May 2005 and 2006, in which the Grain Productivity (PG) was evaluated in $\mathrm{kg}$, the which it was made by weighing the seeds of the ten central plants of the plot, corrected to $13 \%$ moisture and, in followed estimated for hectare. This being the parameter used for the evaluation of inbreeding depression.

\subsection{Coefficient of Endogamy and Inbreeding Depression}

The coefficient of inbreeding (F) was calculated according to Equations 1, 2 and 3, reported by Oliveira et al. (2012), which are expressed as follows:

$$
\mathrm{FPA}=\mathrm{s} /(2-\mathrm{s}) \rightarrow \text { open-pollinated progenies (PA) }
$$

Assuming that the base population is in equilibrium, in relation to the reproductive system.

$$
\begin{gathered}
\mathrm{FAU}=(1+\mathrm{FPA}) / 2 \rightarrow \text { progenies of self-pollination (AU) } \\
\text { FPC }=0 \rightarrow \text { cross-pollination progenies (PC) }
\end{gathered}
$$

where, FPA = coefficient of inbreeding in the progenies PA; FAU = coefficient of inbreeding in the progenies AU; $\mathrm{FPC}=$ coefficient of inbreeding in the progenies $\mathrm{PC} ; \mathrm{S}=$ natural self-pollination rate.

The self-pollination rate was obtained by subtracting the total pollination $(100 \%)$ less the percentage of the cross-pollination rate, which was measured at the time and in the region where the progenies were obtained.

The estimate of inbreeding depression (DE), in percentage, in the self-pollinated progenies relative to the open pollinated progenies was given using Equation 4, reported by Oliveira et al. (2012), being expressed as follows:

$$
D E_{1}=\left[\left(\bar{y}_{P A}-\bar{y}_{A U}\right) / \bar{y}_{P A}\right] \times 100
$$

where, $\bar{y} P A=$ average value of open pollination progeny; $\bar{y} A U=$ average value of self-pollination progeny.

The estimate of the depression (DE), in percentages, in the self-pollinated progenies in relation to the cross progenies, in turn, occurred by means of equation 5, reported by Oliveira et al. (2012), detailed as follows:

$$
D E_{2}=\left[\left(\bar{y}_{P C}-\bar{y}_{A U}\right) / \bar{y}_{P C}\right] \times 100
$$

where, $\bar{y} P C=$ average value of cross-pollinated progeny; $\bar{y} A U=$ average value of the self-pollination progeny.

\subsection{Statistical Analysis}

To evaluate the behavior of the data in relation to different pollination methods was estimated the adjusted normal distribution of the data. The software used was Minitab 17 (Minitab, 2016).

\section{Results and Discussion}

In species whose mode of reproduction occurs naturally by self-pollination (autogamous) inbreeding depression does not occur, opposing the cross-pollinated species. But, it is important to emphasize that in the species whose reproductive system had as mixed, in which its reproduction occurs as much by self-pollination as by cross-pollination, as is the case of castor bean, the effect of depression is linked to the rate of natural self-pollination, of mode that these species have effects on depression intermediates, It is located between the autogamous and the allogamous (Oliveira et al., 2012).

Thereby aiming at the knowledge of the genetic structure of progênies were measured the rates of natural self-pollination, presenting to the municipalities of São Manuel and Araçatuba $74.58 \%$ and $67.33 \%$, respectively. Therefore, the cross-pollination rates ranged from $25.42 \%$ for São Manuel to $32.67 \%$ for Araçatuba. The 
difference between the pollination rates for the two experiment sites can be justified by differences in climatic conditions, in particular by wind intensities and insects pollinators (Nascimento et al., 2012).

The behavior of grain yield of progenies the three types of pollination with respect to the coefficient of inbreeding in São Manuel and Araçatuba are shown in Figure 1.
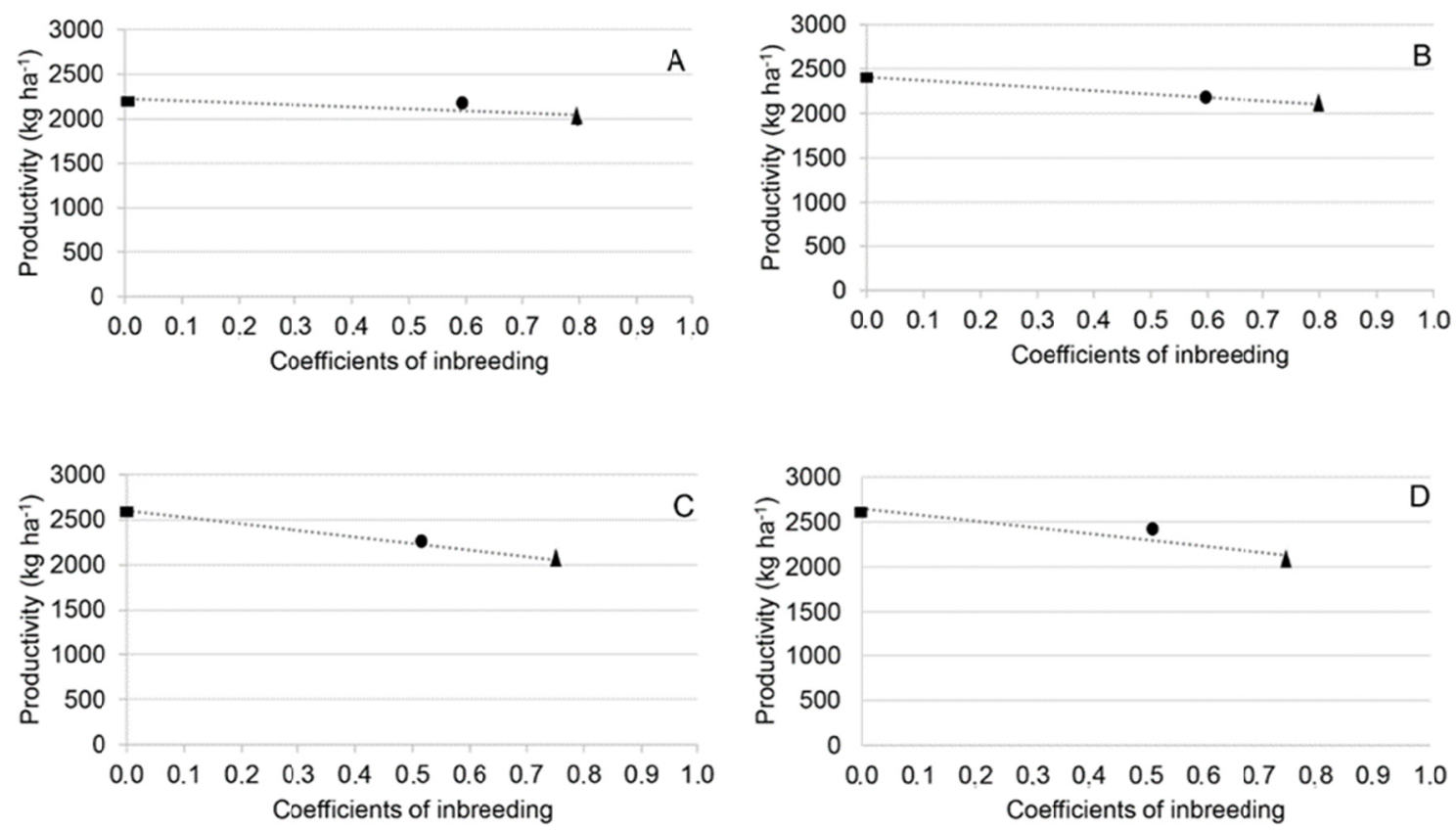

Figure 1. Inbreeding coefficients of the progenies of castor bean in cross-pollination $(\mathbf{\bullet})$, free plonization $(\bullet)$ and self-pollination ( $\mathbf{\Lambda}$ ) for: A) São Manuel, 2004/2005 crop; B) São Manuel, 2005/2006 crop; C) Araçatuba, 2004/2005 crop; D) Araçatuba, 2005/2006 crop

The inbreeding coefficients of the free-pollinated progenies were 0.59 and 0.50 in São Manuel and Araçatuba, respectively. On the other hand, the inbreeding coefficients of the self-pollination progenies were 0.79 and 0.75 in São Manuel and Araçatuba, respectively. In relation to the inbreeding coefficients of cross-pollinated progenies, in both cities, by convention, had values of 0 .

Therefore, it is observed that, generally, the type of pollination in which it was estimated the inbreeding coefficient of 0 (cross-pollination), presented grain yield close to $2500 \mathrm{~kg} \mathrm{ha}^{-1}$, and that with the increase of the coefficient of inbreeding there is a tendency to decrease productivity, as can be seen in progenies from self-pollination, in which there was a coefficient of inbreeding of 0.77 and grain yield around $2000 \mathrm{~kg} \mathrm{ha}^{-1}$, it can be explained by the increase of loci with uniform allele frequencies (Ramalho et al., 2012).

However, analyzing the behavior of grain yield in relation to the coefficient of inbreeding individually in the experiments, it is noticed that in the municipality of São Manuel in the 2004/2005 crop (Figure 1A) the types of cross-pollination, free pollination and self-pollination provided the productivities of 2201,2189 and $1971 \mathrm{~kg} \mathrm{ha}^{-1}$, where the point for open pollination It was above the central trend line. On the other hand, in São Manuel in the 2005/2006 crop (Figure 1B) the grain yield values of cross-pollination and self-pollination increased in relation to the previous year, however, open pollination has reduced its productivity, which led to the exact location about the line of central tendency.

In Araçatuba in the 2004/2005 crop (Figure 1C), cross-pollination provided the highest grain yield with 2589 $\mathrm{kg} \mathrm{ha}^{-1}$ and self-pollination the lowest yield with $2030 \mathrm{~kg} \mathrm{ha}^{-1}$, the same behavior of these two pollinations were verified in Araçatuba in the 2005/2006 crop (Figure 1D), however, while the performance of open pollination lies on the central tendency line of Figure 1C, in Figure 1D it is located slightly above the central trend line.

In Figures 2, 3, 4 and 5, it is observed the frequency distribution of the sampled data of castor bean progenies, resulting from three types of pollination in the municipalities of São Manuel and Araçatuba and in the 2004/2005 and 2005/2006 crops. It is noted that in all experiments progenies from cross-pollination reached the highest 
average productivity values of 2201, 2410, 2589 and $2608 \mathrm{~kg} \mathrm{ha}^{-1}$ for São Manuel in the 2004/2005 crop (Figure 2), São Manuel in the 2005/2006 crop (Figure 3), Araçatuba in the 2004/2005 crop (Figure 4) and Araçatuba in the 2005/2006 crop (Figure 5), respectively.

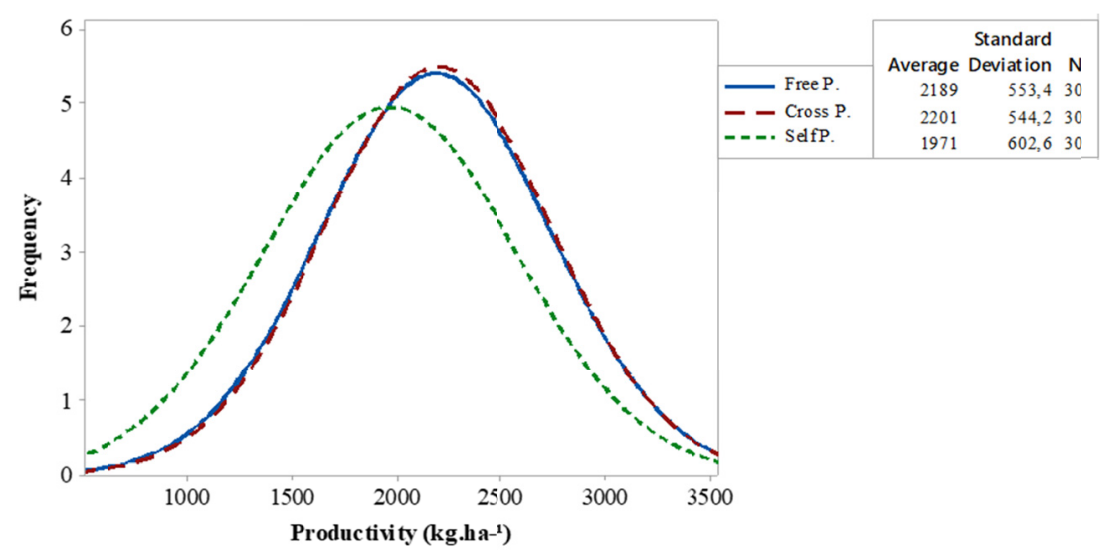

Figure 2. Frequency distribution of the sampled data of castor bean progenies, resulting from three types of pollination in the municipality of São Manuel for the 2004/2005 crop

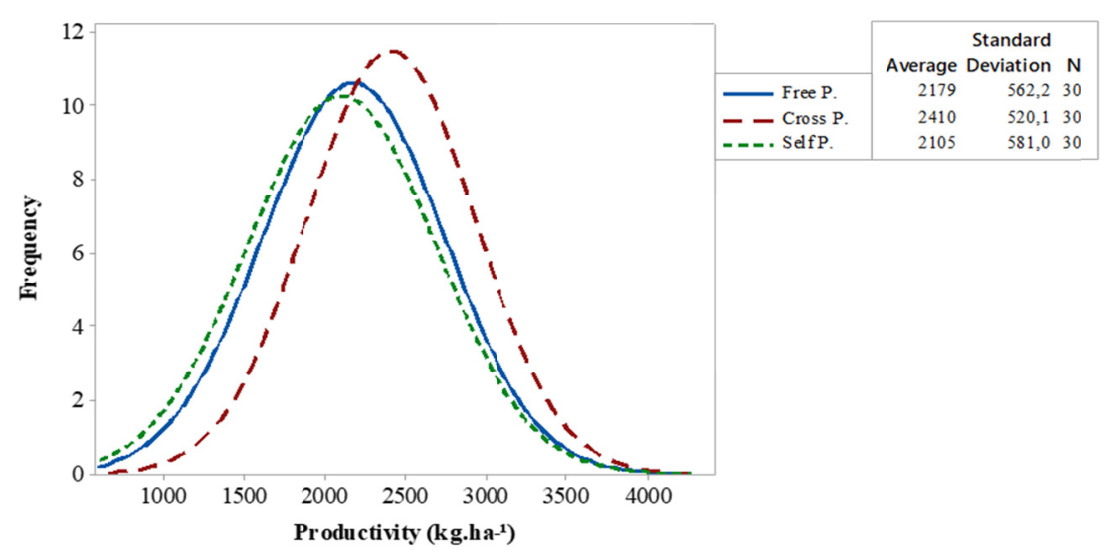

Figure 3. Frequency distribution of the sampled data of the castor bean progenies, resulting from three types of pollination in the municipality of São Manuel for the 2005/2006 crop

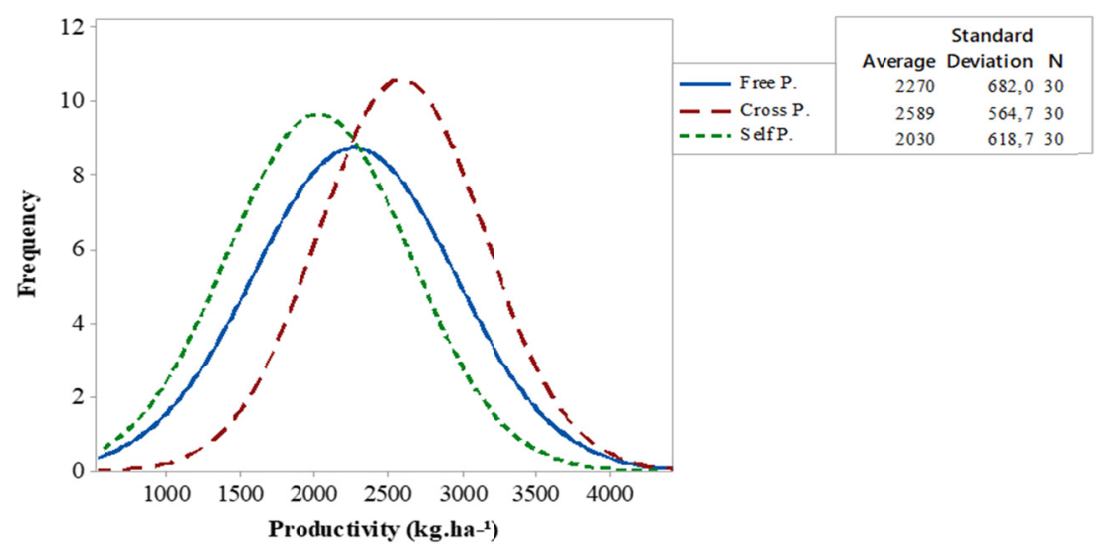

Figure 4. Frequency distribution of the sampled data of the castor bean progenies, resulting from three types of pollination in the municipality of Araçatuba for the 2004/2005 crop 


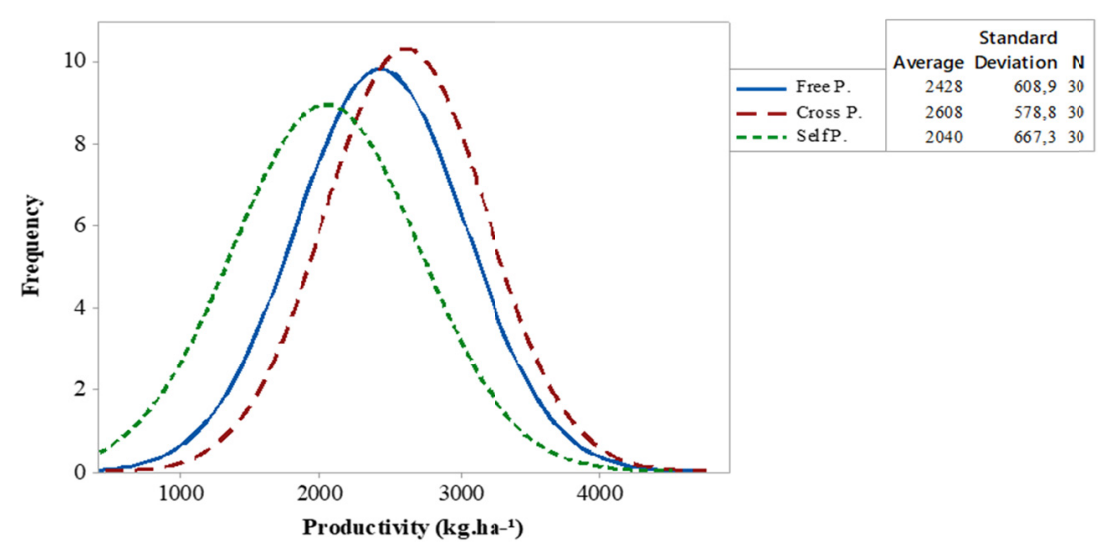

Figure 5. Frequency distribution of the sampled data of the castor bean progenies, resulting from three types of pollination in the municipality of Araçatuba for the 2005/2006 crop

In followed the free-pollinated progenies with average grain yield of 2189, 2179, 2270 and $2428 \mathrm{~kg} \mathrm{ha}^{-1}$ in São Manuel in the 2004/2005 crop, São Manuel in the 2005/2006 crop, Araçatuba in the 2004/2005 crop and Araçatuba in the 2005/2006 crop, respectively, and with the worst incomes are the progenies of self-pollination with 1971, 2105, 2030 and $2040 \mathrm{~kg} \mathrm{ha}^{-1}$ in São Manuel in the 2004/2005 crop, São Manuel in the 2005/2006 crop, Araçatuba in the 2004/2005 crop and Araçatuba in the 2005/2006 crop, respectively.

It is noticed that São Manuel in the 2004/2005 crop and Araçatuba in the 2005/2006 crop, obtained similar distribution, in which the progenies of open pollination and cross pollination showed very similar frequency distribution behavior, reaching a higher number of progenies in the region of the average of these two pollinations. With relation the progenies of self-pollination, the distributions exhibited symmetry a little different from the other pollinations, differing in relation to the number of progenies near the region of the mean, containing a greater dispersion of the data, since the highest value of the standard deviation was obtained.

What concerns about San Manuel in the 2005/2006 crop and Araçatuba in the 2004/2005 crop, it is valid the assertion that the behavior of the distribution of the frequencies of progênies referring to the free pollination system presents itself closer of the progenies of self-pollination, however, the average productivity of the open-pollinated progênies are still higher when compared with self-pollination and smaller than the cross-pollination. Curiously in Araçatuba in the 2004/2005 crop, observed that it differed from the other in relation to the progenies of free pollination, there is seen that they exhibited the highest level of standard deviation, being that in São Manuel in the 2004/2005 crop, São Manuel in the 2005/2006 crop and Araçatuba in the $2005 / 2006$ crop this parameter is higher in the self-pollination progenies.

Thus, as the standard deviation is an indicator of the existing variance, there is a higher probability of increasing the population mean with the selection of the best genotypes in the open pollinated progênies in the municipality of Araçatuba for the 2004/2005 crop, since the basis for genetic improvement is exactly the variability existing in a given population, in addition to having high productivity (Nascimento et al., 2016).

In species whose mode of reproduction is considered as mixed, this system favors the recombination of genes and partially eliminates the genetic load caused by self-fertilization, making it possible the selection of individuals with few or none depression by endogamy, being the knowledge of this depression very important in obtaining pure lines, at which may result in new hybrids or in improved populations (Vencovsky \& Barriga, 1992; Bernini et al., 2013).

It should be noted that depression due to endogamy can be explained by two hypotheses, one is that favorable alleles tend to be dominant or partially dominant, and the other is, that the heterozygous individuals present a higher phenotypic value than homozygotes (Crow \& Kimura, 1970).

It is noted lower mean depression in free-pollinated progenies with $9.96 \%$, however when analyzing the progenies, it observed great variation in depression due to inbreeding, ranging from 51.38 to $-93.89 \%$ considering the open pollinated progenies and of 51.83 to $-119.75 \%$ with relationship the cross-pollinated progenies (Table 1). 
Table 1. Average grain yield, in $\mathrm{kg} \mathrm{ha}^{-1}$, and depression by inbreeding (DE) for each pollination type in São Manuel-SP, 2004/2005 crop

\begin{tabular}{|c|c|c|c|c|c|}
\hline \multirow{2}{*}{ Progenies } & \multicolumn{3}{|c|}{ Pollination } & \multirow{2}{*}{ DE Free } & \multirow{2}{*}{ DE Cross } \\
\hline & Free & Cross & Self & & \\
\hline 1 & 2887.33 & 2796.33 & 1461.67 & 49.38 & 47.73 \\
\hline 2 & 1867.00 & 1874.33 & 2369.33 & -26.91 & -26.41 \\
\hline 3 & 2820.67 & 2832.33 & 2237.33 & 20.68 & 21.01 \\
\hline 4 & 1990.33 & 2005.67 & 1761.33 & 11.51 & 12.18 \\
\hline 5 & 3002.33 & 2985.00 & 2094.67 & 30.23 & 29.83 \\
\hline 6 & 2240.33 & 2214.00 & 2299.00 & -2.62 & -3.84 \\
\hline 7 & 2887.00 & 2966.67 & 1562.67 & 45.87 & 47.33 \\
\hline 8 & 3282.33 & 3261.67 & 1658.00 & 49.49 & 49.17 \\
\hline 9 & 1709.00 & 1695.33 & 1461.33 & 14.49 & 13.80 \\
\hline 10 & 2750.33 & 2776.00 & 1337.33 & 51.38 & 51.83 \\
\hline 11 & 2047.67 & 2090.00 & 2158.33 & -5.40 & -3.27 \\
\hline 12 & 1960.00 & 1894.67 & 1149.00 & 41.38 & 39.36 \\
\hline 13 & 1254.67 & 1107.00 & 2432.67 & -93.89 & -119.75 \\
\hline 14 & 1431.33 & 1681.00 & 1337.67 & 6.54 & 20.42 \\
\hline 15 & 2367.67 & 2393.00 & 2507.33 & -5.90 & -4.78 \\
\hline 16 & 1591.33 & 1621.33 & 2228.67 & -40.05 & -37.46 \\
\hline 17 & 1454.00 & 1523.67 & 2512.00 & -72.76 & -64.87 \\
\hline 18 & 2144.33 & 2180.00 & 3196.67 & -49.08 & -46.64 \\
\hline 19 & 2189.33 & 2218.33 & 1223.67 & 44.11 & 44.84 \\
\hline 20 & 1913.67 & 1884.00 & 2483.67 & -29.79 & -31.83 \\
\hline 21 & 2513.00 & 2524.00 & 2107.00 & 16.16 & 16.52 \\
\hline 22 & 2975.67 & 2966.67 & 2830.00 & 4.90 & 4.61 \\
\hline 23 & 1597.33 & 1617.67 & 1231.33 & 22.91 & 23.88 \\
\hline 24 & 2491.33 & 2521.00 & 1792.00 & 28.07 & 28.92 \\
\hline 25 & 2227.67 & 2220.00 & 1478.00 & 33.65 & 33.42 \\
\hline 26 & 2497.00 & 2519.00 & 3200.33 & -28.17 & -27.05 \\
\hline 27 & 2372.33 & 2357.67 & 1252.67 & 47.20 & 46.87 \\
\hline 28 & 2332.67 & 2315.67 & 1709.00 & 26.74 & 26.20 \\
\hline 29 & 1421.33 & 1443.33 & 2729.00 & -92.00 & -89.08 \\
\hline 30 & 1462.00 & 1549.00 & 1335.33 & 8.66 & 13.79 \\
\hline Average & 2189.37 & 2201.14 & 1971.23 & 9.96 & 10.45 \\
\hline
\end{tabular}

It is noticeable the occurrence of progenies whose values of depression due to endogamy were negative, in this situation the progenies of self-pollination produce more than the progenies of free pollination and cross-pollination, being these progenies indicated to obtain pure lines. On the other hand, the positive depression values indicate that open pollination and cross-pollination stand out about self-pollination, having these progenies great potential to obtain varieties and hybrids (Silva, 2018).

The large variation in levels of depression due to inbreeding had also been reported by Lara-Fioreze et al. (2016), in which evaluating the occurrence of depression due to endogamy in crambe progenies, which is also a kind of mixed reproduction mode, originated from self-pollination, in comparison with progenies of free pollination, observed variation in inbreeding depression from -219.0 to $96.2 \%$ for the grain yield character, should this variation is related to the allelic frequency of the population which gave origin to the evaluated progenies.

Based on the classification criteria of progenies the productivity equal to or greater than $2000 \mathrm{~kg} \mathrm{ha}^{-1}$, depending on the type of pollination, they can be listed in progenies to obtain varieties and hybrids (when in both open pollination how much in cross-pollination exceed the criterion adopted above), pure lines (when they exceed the criterion adopted above in self-pollination) and dual aptitude, being the latter serving both to obtain varieties and hybrids as well as for pure lines. So, considering the productive behavior and the depression due to inbreeding in the municipality of São Manuel in the 2004/2005 crop, progenies 1, 7, 8, 10, 19, 24, 25, 27 and 28 can be selected to obtain varieties and hybrids, seen what had productivity above $2000 \mathrm{~kg} \mathrm{ha}^{-1}$ for free and cross pollinations. The progenies selected to obtain pure linhags were progenies $2,13,16,17,20$ and 29. In addition, progenies $3,5,6,11,15,18,21,22$ and 26 can be used to obtain variety and hybrids, as well as for pure lines. 
It is observed in Table 2, that the highest average inbreeding depression was obtained in the open pollinated progenies with $3.38 \%$, however specifically the progenies, perceive a great variation in inbreeding depression, taking in the open-pollinated and cross-pollinated progenies variation from 49.18 to $-123.20 \%$ and from 56.02 to $-78.19 \%$, respectively.

Table 2. Average grain yield, in $\mathrm{kg} \mathrm{ha}^{-1}$, and depression by inbreeding (DE) for each pollination type in São Manuel-SP, 2005/2006 crop

\begin{tabular}{|c|c|c|c|c|c|}
\hline \multirow{2}{*}{ Progenies } & \multicolumn{3}{|c|}{ Pollination } & \multirow{2}{*}{ DE Free } & \multirow{2}{*}{ DE Cross } \\
\hline & Free & Cross & Self & & \\
\hline 1 & 2946.00 & 2166.67 & 1916.00 & 34.96 & 11.57 \\
\hline 2 & 1860.00 & 2304.67 & 2278.67 & -22.51 & 1.13 \\
\hline 3 & 2772.00 & 2045.67 & 2392.00 & 13.71 & -16.93 \\
\hline 4 & 2004.00 & 2125.00 & 1700.00 & 15.17 & 20.00 \\
\hline 5 & 2988.00 & 2781.67 & 1804.00 & 39.63 & 35.15 \\
\hline 6 & 2208.00 & 2170.33 & 1590.00 & 27.99 & 26.74 \\
\hline 7 & 2928.00 & 3101.67 & 1488.00 & 49.18 & 52.03 \\
\hline 8 & 3276.00 & 2459.33 & 2348.00 & 28.33 & 4.53 \\
\hline 9 & 1674.00 & 2338.33 & 1794.00 & -7.17 & 23.28 \\
\hline 10 & 2796.00 & 2125.00 & 2646.00 & 5.36 & -24.52 \\
\hline 11 & 2028.00 & 2314.00 & 1564.00 & 22.88 & 32.41 \\
\hline 12 & 1890.00 & 2316.67 & 2618.00 & -38.52 & -13.01 \\
\hline 13 & 1086.00 & 2638.33 & 2424.00 & -123.20 & 8.12 \\
\hline 14 & 1476.00 & 2864.33 & 2732.00 & -85.09 & 4.62 \\
\hline 15 & 2364.00 & 2481.33 & 3150.00 & -33.25 & -26.95 \\
\hline 16 & 1500.00 & 2507.67 & 1332.00 & 11.20 & 46.88 \\
\hline 17 & 1494.00 & 1815.33 & 2484.00 & -66.27 & -36.83 \\
\hline 18 & 2130.00 & 2409.00 & 2292.00 & -7.61 & 4.86 \\
\hline 19 & 2190.00 & 4170.67 & 3078.00 & -40.55 & 26.20 \\
\hline 20 & 1884.00 & 2785.00 & 1340.00 & 28.87 & 51.89 \\
\hline 21 & 2484.00 & 1973.33 & 1950.00 & 21.50 & 1.18 \\
\hline 22 & 2958.00 & 1724.67 & 1608.00 & 45.64 & 6.76 \\
\hline 23 & 1650.00 & 1953.00 & 3480.00 & -110.91 & -78.19 \\
\hline 24 & 2574.00 & 1973.33 & 1620.00 & 37.06 & 17.91 \\
\hline 25 & 2136.00 & 3361.00 & 1968.00 & 7.87 & 41.45 \\
\hline 26 & 2520.00 & 2536.33 & 2642.00 & -4.84 & -4.17 \\
\hline 27 & 2352.00 & 2587.00 & 1668.00 & 29.08 & 35.52 \\
\hline 28 & 2184.00 & 2619.67 & 1152.00 & 47.25 & 56.02 \\
\hline 29 & 1524.00 & 2105.67 & 2172.00 & -42.52 & -3.15 \\
\hline 30 & 1488.00 & 1536.00 & 1926.00 & -29.44 & -25.39 \\
\hline Average & 2178.80 & 2409.69 & 2105.22 & 3.38 & 12.64 \\
\hline
\end{tabular}

Therefore, in the municipality of São Manuel in the 2005/2006 crop progenies 1, 4, 5, 6, 7, 11, 25, 27 and 28 can be used to obtain varieties and hybrids, because they presented yields above $2000 \mathrm{~kg} \mathrm{ha}^{-1}$ in open pollination and in cross-pollinations. With respect to progenies 2, 12, 13, 14, 17, 23 and 29 can be used for the synthesis of pure lines (homozygotes), the which after crosses with genetically divergent lines may result in promising hybrids. Aiming at both forms of use, progenies 3, 8, 10, 15, 18, 19 and 26 are as recommended.

Analyzing the two crops in the municipality of São Manuel, it is observed that there were progenies that changed aptitude from one crop to another, indicating a greater level of influence of the climate on them. However, progenies 1, 7, 25, 27 and 28 for obtaining varieties and hybrids, progenies 2, 13, 17 and 29 for synthesis of pure lines and progenies 3, 15, 18 and 26 to double aptitude it remained constant regardless of the crop, thereby exhibiting greater stability for the grain yield parameter.

With regard to Araçatuba, it is noted that the lowest inbreeding depression was expressed in the open-pollinated progenies with a mean depression of $10.59 \%$, restricting the commentary to the progenies, stay evident the great 
variation in depression due to inbreeding, taking in the open-pollinated and cross-pollinated progenies variation from 66.95 to $-86.79 \%$ and from 63.92 to $-65.37 \%$, respectively (Table 3 ).

Table 3. Average yield, in $\mathrm{kg} \mathrm{ha}^{-1}$, and depression by inbreeding (DE) for each type of pollination in Araçatuba-SP, 2004/2005 crop

\begin{tabular}{|c|c|c|c|c|c|}
\hline \multirow{2}{*}{ Progenies } & \multicolumn{3}{|c|}{ Pollination } & \multirow{2}{*}{ DE Free } & \multirow{2}{*}{ DE Cross } \\
\hline & Free & Cross & Self & & \\
\hline 1 & 2493.67 & 2668.67 & 3664.67 & -46.96 & -37.32 \\
\hline 2 & 1463.00 & 3158.00 & 2732.67 & -86.79 & 13.47 \\
\hline 3 & 1771.67 & 2004.33 & 2193.00 & -23.78 & -9.41 \\
\hline 4 & 1503.00 & 2080.00 & 1762.67 & -17.28 & 15.26 \\
\hline 5 & 2055.00 & 2863.67 & 1979.67 & 3.67 & 30.87 \\
\hline 6 & 2805.33 & 2299.00 & 2808.67 & -0.12 & -22.17 \\
\hline 7 & 1584.33 & 1894.00 & 2305.00 & -45.49 & -21.70 \\
\hline 8 & 3904.00 & 2390.00 & 3227.33 & 17.33 & -35.03 \\
\hline 9 & 2315.00 & 1645.00 & 1926.67 & 16.77 & -17.12 \\
\hline 10 & 1640.67 & 1707.67 & 2824.00 & -72.13 & -65.37 \\
\hline 11 & 2614.00 & 2360.00 & 2808.00 & -7.42 & -18.98 \\
\hline 12 & 2031.67 & 3154.00 & 1775.67 & 12.60 & 43.70 \\
\hline 13 & 2560.33 & 3300.33 & 1880.67 & 26.55 & 43.02 \\
\hline 14 & 1037.33 & 3306.67 & 1632.33 & -57.36 & 50.64 \\
\hline 15 & 2870.33 & 2940.67 & 1962.67 & 31.62 & 33.26 \\
\hline 16 & 3121.67 & 3407.33 & 2207.00 & 29.30 & 35.23 \\
\hline 17 & 1929.67 & 2315.67 & 1618.00 & 16.15 & 30.13 \\
\hline 18 & 2247.00 & 2586.33 & 1261.33 & 43.87 & 51.23 \\
\hline 19 & 2778.33 & 3296.67 & 2042.00 & 26.50 & 38.06 \\
\hline 20 & 1258.33 & 1830.33 & 1479.33 & -17.56 & 19.18 \\
\hline 21 & 2740.67 & 2349.00 & 905.67 & 66.95 & 61.44 \\
\hline 22 & 1359.00 & 1543.67 & 1493.67 & -9.91 & 3.24 \\
\hline 23 & 2635.00 & 2600.00 & 1984.67 & 24.68 & 23.67 \\
\hline 24 & 2562.00 & 2485.00 & 2244.33 & 12.40 & 9.68 \\
\hline 25 & 1761.67 & 3106.67 & 1473.33 & 16.37 & 52.58 \\
\hline 26 & 1911.00 & 3376.67 & 1582.00 & 17.22 & 53.15 \\
\hline 27 & 2479.33 & 3219.33 & 1161.67 & 53.15 & 63.92 \\
\hline 28 & 3477.67 & 2748.00 & 1997.33 & 42.57 & 27.32 \\
\hline 29 & 2123.33 & 2251.00 & 1619.00 & 23.75 & 28.08 \\
\hline 30 & 3066.33 & 2793.00 & 2337.67 & 23.76 & 16.30 \\
\hline Average & 2270.01 & 2589.36 & 2029.69 & 10.59 & 21.61 \\
\hline
\end{tabular}

In this scenario, Araçatuba in the 2004/2005 crop, the progenies 5, 12, 13, 15, 18, 21, 23, 27, 28 and 29 can be used to obtain varieties and hybrids. Concerning progenies $2,3,7$ and 10, they are likely to be employed for the production of inbred lines. With regard to progenies of double aptitude, are progenies highlighted 1, 6, 8, 11, 16, 19,24 and 30 .

It is observed for Araçatuba in the 2005/2006 crop, that in general free pollination provided the lowest level of inbreeding depression with an average of $15.99 \%$, considering only the progenies individually, it is noted wide variation in this depression, taking in the open-pollinated and cross-pollinated progenies variation from 59.93 to $-115.10 \%$ and from 62.52 to $-118.91 \%$, respectively (Table 4 ). 
Table 4. Average grain yield, in $\mathrm{kg} \mathrm{ha}^{-1}$, and depression by inbreeding (DE) for each type of pollination in Araçatuba-SP, 2005/2006 crop

\begin{tabular}{|c|c|c|c|c|c|}
\hline \multirow{2}{*}{ Progenies } & \multicolumn{3}{|c|}{ Pollination } & \multirow{2}{*}{ DE Free } & \multirow{2}{*}{ DE Cross } \\
\hline & Free & Cross & Self & & \\
\hline 1 & 2686.00 & 3052.00 & 1144.00 & 57.41 & 62.52 \\
\hline 2 & 2411.73 & 3861.67 & 1872.64 & 22.35 & 51.51 \\
\hline 3 & 2662.20 & 2340.73 & 1066.67 & 59.93 & 54.43 \\
\hline 4 & 3096.27 & 2706.47 & 2403.67 & 22.37 & 11.19 \\
\hline 5 & 2454.80 & 2605.93 & 1906.08 & 22.35 & 26.86 \\
\hline 6 & 2171.47 & 2575.60 & 1686.08 & 22.35 & 34.54 \\
\hline 7 & 2848.07 & 2121.47 & 1219.00 & 57.20 & 42.54 \\
\hline 8 & 2255.33 & 2578.20 & 1751.20 & 22.35 & 32.08 \\
\hline 9 & 3524.00 & 2706.47 & 1711.60 & 51.43 & 36.76 \\
\hline 10 & 2880.93 & 3693.33 & 2236.96 & 22.35 & 39.43 \\
\hline 11 & 3205.07 & 3758.67 & 2488.64 & 22.35 & 33.79 \\
\hline 12 & 2738.13 & 2609.05 & 2126.08 & 22.35 & 18.51 \\
\hline 13 & 2486.53 & 2575.01 & 1054.00 & 57.61 & 59.07 \\
\hline 14 & 3063.40 & 2695.53 & 2378.64 & 22.35 & 11.76 \\
\hline 15 & 2535.27 & 2532.69 & 1968.56 & 22.35 & 22.27 \\
\hline 16 & 2929.67 & 2150.89 & 2274.80 & 22.35 & -5.76 \\
\hline 17 & 2684.87 & 2667.01 & 2084.72 & 22.35 & 21.83 \\
\hline 18 & 2981.80 & 1993.57 & 2056.56 & 31.03 & -3.16 \\
\hline 19 & 2621.40 & 2253.01 & 3172.67 & -21.03 & -40.82 \\
\hline 20 & 2102.33 & 2694.61 & 1632.40 & 22.35 & 39.42 \\
\hline 21 & 3280.33 & 2034.05 & 4452.67 & -35.74 & -118.91 \\
\hline 22 & 1132.33 & 2825.25 & 2435.67 & -115.10 & 13.79 \\
\hline 23 & 1644.93 & 2561.21 & 2211.67 & -34.45 & 13.65 \\
\hline 24 & 1885.00 & 1517.33 & 1843.00 & 2.23 & -21.46 \\
\hline 25 & 1506.27 & 2960.49 & 2558.00 & -69.82 & 13.60 \\
\hline 26 & 2187.47 & 2424.13 & 2397.33 & -9.59 & 1.11 \\
\hline 27 & 2213.47 & 1760.53 & 2301.00 & -3.95 & -30.70 \\
\hline 28 & 1665.73 & 3639.00 & 1480.00 & 11.15 & 59.33 \\
\hline 29 & 1535.87 & 2661.49 & 1613.67 & -5.07 & 39.37 \\
\hline 30 & 1440.40 & 1677.40 & 1660.33 & -15.27 & 1.02 \\
\hline Average & 2427.70 & 2607.76 & 2039.61 & 15.99 & 21.79 \\
\hline
\end{tabular}

Taking into account the behavior of the progenies in Araçatuba in the 2005/2006 crop, is notorious ability of the progenies $1,2,3,5,6,7,8,9,13,15$ and 20 in obtaining varieties and hybrids, with also progenies 18, 22, 23, 25 and 27 for the production of pure lines. It is also possible to perceive occurrences of progenies with these two aptitudes, which were progenies 4, 10,11,12,14, 16, 17, 19, 21 and 26.

Observing the two crops in the municipality of Araçatuba, despite providing the highest mean values for grain yield, there were more changes in aptitudes of progenies from one crop to another when compared with the performances the same in the municipality of São Manuel. However, some progenies exhibited the same aptitude in the two crops, where progenies 5, 13 and 15 were classified to obtain varieties and hybrids, and progenies 11, 16 and 19 both for synthesis varieties and hybrids as well as for the production of pure lines. It is noteworthy that, no progeny maintained the classification only to obtain pure lines in the two crops.

It is important to stress that, in the four experiments conducted, in all of them cross-pollination provided the highest yields of grains, being able this phenomenon be explained by the theory of partial dominance, being depression due to inbreeding proportional to the degree of dominance (Allard, 1960; Falconer, 1987).

\section{Conclusion}

The reflection of the coefficient of inbreeding in productivity shows an inversely proportional behavior, that is, as one increases the inbreeding coefficient decreases the grain yield. 
There were differences in the frequency distribution of the data for the three types of pollination, however, the average grain yield is displayed in decreasing order for cross-pollination, open pollination and self-pollination, in this order.

The values of depression due to inbreeding exhibited a wide range of variation, however, in general terms, the depression based on open pollination presented the lowest values.

\section{References}

Allard, R. W. (1960). Principles of plant breeding (p. 485). New York: Wiley.

Alvares, C. A., Stape J. L., Sentelhas, P. C., Gonçalves, J. L. M., \& Sparovek, G. (2014). Köppen's climate classification map for Brazil. Meteorologische Zeitschrift, 22(6), 711-728. https://doi.org/10.1127/ 0941-2948/2013/0507

Bernini, C. S., Paterniani, M. E. A. G. Z., Duarte, A. P., Gallo, P. B., Guimarães, P. S., \& Rovaris, S. R. S. (2013). Depressão endogâmica e heterose de híbridos de populações $\mathrm{F}_{2}$ de milho no estado de São Paulo. Bragantia, 72(3), 217-223. https://doi.org/10.1590/brag.2013.038

Borém, A. (2005). Melhoramento de espécies cultivadas (p. 525). Viçosa: Editora UFV.

Borém, A. (2009). Hibridação artificial de plantas (2nd ed., p. 625). Viçosa: Editora UFV.

Borém, A., \& Miranda, G. V. (2013). Melhoramento de plantas (6th ed., p. 523). Viçosa: Editora UFV.

Bueno, L. C. S., Mendes, A. N. G., \& Carvalho, S. P. (2006). Melhoramento de plantas: Princípios e procedimentos (p. 319). Lavras: Editora UFLA.

Chierice, G. O., \& Claro Neto, S. (2007). Aplicação Industrial do óleo. In D. M. P. Azevedo, \& N. E. M. Beltrão (Eds.), O Agronegócio da mamona no Brasil (pp. 417-447). Brasília: Embrapa.

CONAB (Companhia Nacional de Abastecimento). (2017). Safras: Série histórica das safras. Brasília: CONAB. Retrieved from https://www.conab.gov.br/info-agro/safras/serie-historica-das-safras?start=10

Crow, J. F., \& Kimura, M. (1970). An introduction to population genetics theory (p. 656). New York: Harper \& Row.

Falconer, D. S. (1987). Introduction to quantitative genetic (p. 279). Viçosa: Editora UFV.

FAO (Food and Agricultura Organization of the United States Nations). (2016). Faostat. Roma: FAO. Retrieved from https://www.fao.org/faostat/en/\#rankings/countries_by_commodity

Gonçalves, R. W., Costa, M. D., Rocha Júnior, V. R., Costa, M. R., Silva, E. S. P., \& Ribeiro, A. M. F. (2011). Efeito da endogamia sobre características reprodutivas em um rebanho da raça Mangalarga Marchador. Revista Brasileira de Saúde e Produção Animal, 12(3), 641-649.

Lara-Fioreze, A. C. C., Pivetta, L. G., \& Zanotto, M. D. (2016). Inbreeding depression in crambe. Pesquisa Agropecuária Tropical, 46(4), 401-406. https://doi.org/10.1590/1983-40632016v4641811

Lopes, F. F. M., Beltrâo, N. E. M., Lopes Neto, J. P., \& Pedroza, J. P. (2008). Crescimento inicial de genótipos de mamoneira com sementes submetidas ao envelhecimento acelerado. Revista Brasileira de Oleaginosas e Fibrosas, 12(2), 69-79.

MINITAB. (2016). Minitab 17. State College: Minitab Inc.

Moshkin, V. A. (1986). Economic importance and regions of cultivation of castor. Castor (pp. 1-3). New Delh: Oxonian Press.

Nascimento, W. M., Gomes, E. M. L., Batista, E. A., \& Freitas, R. A. (2012). Utilização de agentes polinizadores na produção de sementes de cenoura e pimenta doce em cultivo protegido. Horticultura Brasileira, 30(3), 494-498. https://doi.org/10.1590/S0102-05362012000300023

Nascimento, W. M., Andrade, K. P., Freitas, R. A., Silva, G. O., \& Boiteux, L. S. (2016). Germinação de sementes de tomateiro em diferentes temperaturas: Variabilidade fenotípica e heterose. Horticultura Brasileira, 34(2), 216-222. https://doi.org/10.1590/S0102-053620160000200011

Oliveira, I. J., Zanotto, M. D., Krieger, M., \& Vencovsky, R. (2012). Inbreeding depression in castor bean (Ricinus communis L.) progênies. Crop Breeding and Applied Biotechnology, 12(4), 269-276. https://doi.org/10.1590/S1984-70332012000400006

Ramalho, M. A. P., Santos, J. B., Pinto, C. A. B. P., Souza, E. A., Gonçalves, F. M. A., \& Souza, J. C. (2012). Genética na agropecuária (5th ed., p. 565). Lavras: Editora UFLA. 
Savy Filho, A. (2009). Hibridação em mamona. In A. Borém (Ed.), Hibridação artificial de plantas (pp. 390-402). Viçosa: Editora UFV.

Silva, A. G. (2018). Depressão por endogamia em híbridos simples de sorgo granífero sob estresse hídrico (Master thesis published, Universidade Estadual de Goiás, Ipameri, Brazil).

Toppa, E. V. B., Silva, C. J., Zoz, T., \& Silva, T. M. N. (2012). Análise comparativa dos métodos de obtenção de linhagens "standard” e híbridos crípticos. Revista Verde, 7(1), 28-31.

Toppa, E. V. B., Silva, J., Sartori, M. M. P., \& Zanotto, M. D. (2018). Comparison of castor beans hybrids produced by the conventional method and by the cryptic hybrid method. Journal of Experimental Agriculture International, 2(2), 1-12. https://doi.org/ 10.9734/JEAI/2018/38569

Vencovsky, R., \& Barriga, P. (1992). Genética biométrica no fitomelhoramento (p. 486). Ribeirão Preto: Sociedade Brasileira de Genética.

Vieira, R. M., \& Lima, E. F. (1999). Importância sócio-econômica e melhoramento genético da mamoneira no Brasil. In M. A. Queiroz, C. O. Goedert, \& S. R. R. Ramos (Eds.), Recursos genéticos e melhoramento de plantas para o nordeste brasileiro (pp. 913-920). Petrolina: Embrapa.

\section{Copyrights}

Copyright for this article is retained by the author(s), with first publication rights granted to the journal.

This is an open-access article distributed under the terms and conditions of the Creative Commons Attribution license (http://creativecommons.org/licenses/by/4.0/). 